\title{
The relevance of household contacts tracing among child contacts of patients with multidrug-resistant tuberculosis
}

\author{
O.M. Raznatovska ${ }^{1}$,A.S. Moskaliuk ${ }^{1}$, T.A. Grekova ${ }^{1}$, L.I. Chernyshova ${ }^{2}$, 0. O. Pushnova ${ }^{2}$, T.I. Shelestina \\ 1. Zaporizhzhia State Medical University, Zaporizhzhia \\ 2. Municipal Institution “Zaporizhzhia Regional Tuberculosis Clinical Dispensary”, Zaporizhzhia \\ Conflict of interest: none
}

BACKGROUND. The World Health Organization (WHO) reports an unknown contact history of pediatric tuberculosis (TB), especially in children younger than 5 years old. Tracing pediatric household contacts of patients with multidrug-resistant TB (MDR-TB) is considered to be a highly effective intervention for detection of new cases of chemoresistant TB in children and timely prevention of its transmission.

OBJECTIVE. To study the nature of TB process manifestations and concordance of mycobacterium tuberculosis (MBT) drug resistance profiles in household child contacts of patients with MDR-TB.

MATERIALS AND METHODS. The nature of TB process manifestations and concordance of MBT drug resistance profiles in 12 household child contacts of patients with MDR-TB in 6 households ( 6 adult MDR-TB index patients, IP) were studied. Adults and children were examined and treated in the Pulmonary Tuberculosis Department No 3 and in the Pediatric Department of the Clinical Base of the Department of Phthisiology and Pulmonology of Zaporizhzhia State Medical University at the Municipal Institution "Zaporizhzhia Regional Tuberculosis Clinical Dispensary".

RESULTS AND DISCUSSION. The tracing of children who were household contacts of the MDR-TB IP revealed the following features. The incidence of child TB was 2 times higher than that of contact adults (44\% vs. $20 \%$ ). Moreover, the incidence among children younger than 2 years of age was almost 3 times higher than in children across other age groups ( $54.5 \%$ vs. $18.2 \%$ in children younger than 5 years of age and $18.2 \%$ in children aged 5 years and older). The children were non-BCG vaccinated in $63.6 \%$ of cases. There was an alarmingly high rate of non-BCG vaccinated children, namely $83.3 \%$ among individuals younger than 2 years of age and all of those younger than 5 years of age (100\%). The children mostly presented small clinical forms of non-destructive TB: intrathoracic lymph node TB (36.4 \%), MBT complex (36.4 \%) and focal TB (18.2\%). Most of the children (63.6\%) who developed TB were detected within the first year of IP with MDR-TB follow-up, and it is worthy of note that in the majority of cases (4 households; $66.6 \%$ ). With respect to the concordance of MBT drug resistance profiles between the children and MDR-TB IP in the households, diagnosis in children was microbiologically confirmed in only 3 cases ( 3 households) demonstrating the complete concordance of profiles in each one. At the same time, the complete concordance of MBT drug resistance profiles between adult household contacts and the MDR-TB IP was also recorded in 3 cases. As is evident, across the household contacts group aged between 0 and 18 years who were exposed to the MDR-TB IP, the most susceptible to develop TB were non-BCG vaccinated children younger than 2 years. More worryingly is that among 3 microbiologically conformed individuals of this age group, 2 children younger than 2 years were found to have their own drug resistant MTB isolates.

CONCLUSIONS. Tracing household child contacts of MDR-TB IP is particularly effective for timely detection of active TB within the first year of MDR-TB IP follow-up. Non-BCG vaccinated children younger than 2 years of age are at the highest risk for MDR-TB followed by non-BCG vaccinated children younger than 5 years of age. The early detection and timely antimycobacterial therapy initiation based on drug susceptibility test results of a MDR-TB IP is a guarantee not only for an effective treatment but also for a reduction in the MDR-TB transmission to other persons.

KEY WORDS: contact tracing, household, children, multidrug-resistant tuberculosis

\section{Актуальність відстеження дітей, які контактували 3 хворими на мультирезистентний туберкульоз у межах домогосподарства}

\author{
О.М. Разнатовська ${ }^{1}$, А.С. Москалюк ${ }^{1}$, Т.А. Грекова ${ }^{1}$, Л.І. Чернишова ${ }^{2}$, О.О. Пушнова², Т.І. Шелестіна ${ }^{2}$ \\ 1. Запорізький державний медичний університет, м. Запоріжжя \\ 2. КУ «Запорізький обласний протитуберкульозний клінічний диспансер», м. Запоріжжя \\ Конфлікт інтересів: відсутній
}

ОБґ'РУНТУвАНня. Експерти Всесвітньої організації охорони здоров’я (ВООЗ) вказують, що захворювання на туберкульоз (ТБ) у дитячому віці, особливо до 5 років, свідчить про невстановлене джерело інфекції. Відстеження дітей, які контактували з хворими на мультирезистентний ТБ (МРТБ) у межах домогосподарства, $\epsilon$ високоефективним втручанням для своєчасного виявлення нових випадків хіміорезистентного ТБ у дітей і запобігання його передачі. 


\section{— ОРИГІНАЛЬНЕ ДОСЛІДЖЕННЯ}

META. Вивчення характеру проявів туберкульозного процесу та збігу профілів лікарської стійкості мікобактерій туберкульозу (МБТ) у дітей, які контактували з хворими на МРТБ у межах домогосподарства.

MATEPIAЛИ ТА МЕТОДИ. Характер проявів туберкульозного процесу та збіг профілів лікарської стійкості МБТ вивчалися в 12 дітей, які контактували з хворими на МРТБ у межах 6 домогосподарств (6 дорослих індексних пацієнтів (ІП) з МРТБ). Обстеження та стаціонарне лікування дорослих і дітей відбувалися у відділенні легеневого туберкульозу № 3 та в дитячому відділенні клінічної бази кафедри фтизіатрії і пульмонології Запорізького державного медичного університету в Комунальній установі «Запорізький обласний протитуберкульозний клінічний диспансер».

РЕзУЛЬТАТИ ТА ÏХ ОБГОВОРЕНня. Відстеження дітей, які контактували з ІП з МРТБ У межаХ домогосподарства, дало змогу виявити такі особливості. Дитяча захворюваність на ТБ у 2 рази перевищувала таку в контактних дорослих (44 \% проти 20 \%). При цьому захворюваність серед дітей віком до 2 років була вищою майже в 3 рази щодо інших розрізів дитячого віку (54,5 \% проти 18,2 \% у віці до 5 років і 18,2 \% у віці понад 5 років). У 63,6 \% випадків діти не були щеплені вакциною БЦж. Насторожує той факт, що нещепленими були 83,3 \% дітей до 2 років і всі діти до 5 років (100\%). Серед клінічних форм захворювання в дітей переважали малі форми недеструктивного ТБ: ТБ внутрішньогрудних лімфатичних вузлів (36,4 \%), первинний туберкульозний комплекс $(36,4$ \%) і вогнищевий ТБ (18,2 \%). Більшість дітей (63,6 \%), які захворіли на ТБ, виявлені в перший рік спостереження за ІП з МРТБ, при цьому в переважній кількості домогосподарств - 4 (66,6 \%). Щодо збігу профілів лікарської стійкості МБТ у домогосподарствах у дітей з ІП з МРТБ, то бактеріовиділення зареєстровано лише в 3 дітей (3 домогосподарства) й у всіх випадках встановлено повний збіг профілів. При цьому в 3 домогосподарствах у дорослих контактних осіб зареєстровано також повний збіг профілів лікарської стійкості МБТ з ІП з МРТБ. Отже, серед контингенту віком 0-18 років, які контактували з ІП з МРТБ у межах домогосподарства, найбільш схильними до розвитку ТБ були невакциновані діти до 2 років. Викликає занепокоєння те, що серед 3 бактеріовиділювачів цього контингенту власна лікарська стійкість МБТ була діагностована у 2 дітей віком до 2 років.

ВИСновки. Відстеження дітей, які контактували з ІП з МРТБ у межах домогосподарства, $\epsilon$ особливо корисним для своєчасного виявлення в них активного ТБ у перший рік спостереження за ІП з МРТБ. Найбільшою групою ризику МРТБ $\epsilon$ не щеплені вакциною БЦЖ діти до 2 років, на другому місці - не щеплені вакциною БЦЖ діти до 5 років. Раннє виявлення та своєчасне призначення антимікобактеріальної терапії з урахуванням результатів тесту на медикаментозну чутливість ІП з МРТБ $€$ запорукою не лише ефективного лікування, але й скорочення подальшої передачі МРТБ.

ключовІ СловА: відстеження контакту, домогосподарства, діти, мультирезистентний туберкульоз.

\section{Актуальность отслеживания детей, контактировавших с больными мультирезистентным туберкулезом в пределах домохозяйства}

Е.Н. Разнатовская ${ }^{1}$, А.С. Москалюк ${ }^{1}$, Т.А. Грекова ${ }^{1}$, Л.И. Чернышова ${ }^{2}$, О.А. Пушнова ${ }^{2}$, Т.И. Шелестина ${ }^{2}$

1. Запорожский государственный медицинский университет, г. Запорожье

2. КУ «Запорожский областной противотуберкулезный клинический диспансер», г. Запорожье

Конфликт интересов: отсутствует

ОБоСновАНИЕ. Эксперты Всемирной организации здравоохранения (ВОЗ) указывают, что заболевание туберкулезом (ТБ) в детском возрасте, особенно до 5 лет, свидетельствует о неустановленном источнике инфекции. Отслеживание детей, контактировавших с больными мультирезистентным ТБ (МРТБ) в пределах домохозяйства, является высокоэффективным вмешательством для своевременного выявления новых случаев химиорезистентного ТБ у детей и предупреждения его передачи.

ЦЕль. Изучение характера проявлений туберкулезного процесса и совпадения профилей лекарственной устойчивости микобактерий туберкулеза (МБТ) у детей, которые контактировали с больными МРТБ в пределах домоХозяЙСтва.

МАТЕРИАЛЫ И МЕТОДЫ. Характер проявлений туберкулезного процесса и совпадения профилей лекарственной резистентности МБТ изучались у 12 детей, контактировавших с больными МРТБ в пределах 6 домохозяйств (6 взрослых индексных пациентов (ИП) с МРТБ). Обследование и стационарное лечение взрослых и детей проводились в отделении легочного туберкулеза № 3 и в детском отделении клинической базы кафедры фтизиатрии и пульмонологии Запорожского государственного медицинского университета в Коммунальном учреждении «Запорожский областной противотуберкулезный клинический диспансер». 
РЕЗУЛЬТАТЫ И ИХ ОБСУЖДЕНИЕ. Отслеживание детей, контактировавших с ИП с МРТБ в пределах домохозяйства, позволило выявить следующие особенности. Детская заболеваемость ТБ в 2 раза превышала таковую у контактных взрослых (44 \% против 20 \%). При этом заболеваемость среди детей в возрасте до 2 лет была выше почти в 3 раза относительно других разрезов детского возраста (54,5 \% против 18,2 \% в возрасте до 5 лет и 18,2 \% в возрасте более 5 лет). В 63,6 \% случаев дети не были привиты вакциной БЦж. Настораживает тот факт, что непривитыми были 83,3 \% детей в возрасте до 2 лет и все дети в возрасте до 5 лет (100\%). Среди клинических форм заболевания у детей преобладали малые формы недеструктивного ТБ: ТБ внутригрудных лимфатических узлов (36,4 \%), первичный туберкулезный комплекс (36,4 \%) и очаговый ТБ (18,2 \%). Большинство детей (63,6 \%), которые заболели ТБ, выявлены в первый год наблюдения за ИП с МРТБ, при этом в подавляющем числе домохозяйств 4 (66,6 \%). Что касается совпадения профилей лекарственной устойчивости МБТ в домохозяйствах у детей с ИП с МРТБ, то бактериовыделение зарегистрировано только у 3 детей (3 домохозяйства) и во всех случаях установлено полное совпадение профилей. При этом в 3 домохозяйствах у взрослых контактных лиц зарегистрировано также полное совпадение профилей лекарственной устойчивости МБТ с ИП с МРТБ. Таким образом, среди контингента в возрасте 0-18 лет, контактировавших с ИП с МРТБ в пределах домохозяйства, наиболее склонными к развитию ТБ были невакцинированные дети до 2 лет. Вызывает беспокойство то, что среди 3 бактериовыделителей этого контингента собственная лекарственная устойчивость МБТ была диагностирована у 2 детей в возрасте до 2 лет. выводы. Отслеживание детей, контактировавших с ИП с МРТБ в пределах домохозяйства, особенно полезно для своевременного выявления у них активного ТБ в первый год наблюдения за ИП с МРТБ. Наибольшей группой риска МРТБ являются не привитые вакциной БЦЖ дети до 2 лет, на втором месте - не привитые вакциной БЦЖ дети до 5 лет. Раннее выявление и своевременное назначение антимикобактериальной терапии с учетом результатов теста на медикаментозную чувствительность ИП с МРТБ являются залогом не только эффективного лечения, но и сокращения дальнейшей передачи МРТБ.

Ключєвыє СлОВА: отслеживание контакта, домохозяйства, дети, мультирезистентный туберкулез.

\section{Introduction}

The World Health Organization (WHO) reports an unknown contact history of pediatric tuberculosis (TB), especially in children younger than 5 years old [1].

A household contact person, as defined by the WHO [2], is a person who had been in close and frequent contact by living in the same house with a TB index patient (IP; a patient included in contact tracing for contacts, although this person may not be an infectious source case) for at least 3 days in between 3 weeks before diagnosis and 1 week after diagnosis and commencement of treatment. In this context, there is an emphasis on ensuring careful clinical observation and strict control of active form of TB development among people who had contact with multidrug-resistant TB (MDR-TB) patients.

The literature describes [3, 4] interesting cases of contacts where sputum-smear negative TB children (15 and 9 years old) spread TB to classmate contacts. In both cases, the children had clinical symptoms and continued to attend school. The authors indicate that sputum-smear negative TB children can be a source of tuberculosis infection. Therefore, such cases should be considered contagious until proven otherwise. And contact tracing should be carried out among contacting children with symptoms of TB.

However, the most susceptible to TB infection in index cases are contacts within households due to their close proximity [5].

According to data collected by M.C. Becerra et al. [6], who examined 693 households of IP, the frequency of active MDR-TB among contacts was $60 \%$, and the frequency of active extensively drug-resistant (XDR) TB was nearly 2 times higher during the 4-year follow-up.
M.C. Becerra et al. [7] conducted another study - retrospective cohort monitoring of child and adult household contacts of patients treated for MDR-TB. Researchers found that childhood TB incidence was $20 \%$ of cases, $47.6 \%$ of whom constituted TB incidence rate per 100,000 child-years in year 1 and $87.5 \%$ were diagnosed with MDR-TB. Moreover, it was found that TB disease rates in children aged more than 1 year were not significantly different from that observed in adults, and child contacts had TB disease rates 30 times higher than in the general population. The authors state that implementation of pediatric household contact investigations is a crucial and necessary component in early diagnosis and treatment of MDR-TB patients, regardless of a child's age.

Based on meta-analysis conducted, G.J. Fox et al. [8] also found that contacts of TB patients are a high-risk group for developing TB, especially within the first year, while noting that children younger than 5 years of age and people living with human immunodeficiency virus (HIV) are particularly at risk.

There is a meta-analysis performed by L. Lancellaa et al. [9] indicating that the risk of TB progression in contact persons aged 0-18 years depends on age being about $15 \%$ in adolescents, $24 \%$ in children aged $1-5$ years, and $40-50 \%$ in those aged 2 years and younger. In addition, the tendency to develop rapid TB progression is more frequent in children particularly if they are aged younger than 2 years.

The WHO Program Guidelines for Drug-Resistant TB treatment [10] states that symptomatic TB household contacts of patients with MDR-TB should undergo more enhanced diagnosis than those contacts of drug-sensitive TB patients. This particularly concerns young children living with MDR-TB patients, as they are at a high risk of infection and active 
progressive MDR-TB development. Diagnostic examination of contact children to MDR-TB patients should include chest $\mathrm{X}$-ray, tuberculin skin test, sputum or gastric lavage fluid (in young children) examination (Xpert MTB/RIF or sputum smear microscopy, if not available, culture and drug susceptibility test, DST) as well as HIV testing. As soon as a contact child to a MDR-TB patient begins to meet the criteria for active TB diagnosis, treatment should be started using the same antimycobacterial therapy (AMBT) regimen taking into account the same DST data of the IP (MDR-TB source).

In addition to the diagnostic measures recommended by the WHO, L. Lancellaa et al. [9] indicate the need for a IFN- $\gamma$ release assay (IGRA) (QuantiFERON), especially for subjects who have been vaccinated with BCG and HIV infected as well as for high-risk of MDR-TB children (household contacts of MDR-TB patients).

J.B. Parr et al. [11] studied the concordance of mycobacterium tuberculosis (MBT) drug resistance profiles in households of patients with MDR-TB and contacts of them who subsequently developed MDR-TB. The authors found that among household contacts who developed TB, $88.4 \%$ had isolates resistant to isoniazid and rifampicin, and $40 \%$ of contacts had isolates with MBT drug resistance results that matched the purported source of MDR-TB.

Studies of T.S. Shah et al. [12] showed that household contacts of patients living with MDR-TB had MBT drug resistance results concordant with those of the source case in $50 \%$.

Thus, tracing pediatric household contacts of patients with MDR-TB is considered to be a highly effective intervention for detection of new cases of chemoresistant TB in children and timely prevention of its transmission.

The purpose of this work is to study the nature of TB process manifestations and concordance of MBT drug resistance profiles in household child contacts of patients with MDR-TB.

\section{Materials and methods}

The nature of TB process manifestations and concordance of MBT drug resistance profiles in 12 household child contacts of patients with MDR-TB in 6 households ( 6 adult MDR-TB IP) were studied. Adults and children were examined and treated in the Pulmonary Tuberculosis Department (PTD) No 3 and the Pediatric Department of the Clinical Base of the Department of Phthisiology and Pulmonology of Zaporizhzhia State Medical University at the Municipal Institution "Zaporizhzhia Regional Tuberculosis Clinical Dispensary” (ZRTBCD).

\section{Results}

Household 1 (fig. 1). The IP is a 37-year-old man without a prior history of TB infection. A specific process in the lungs was revealed when the patient presented with bronchopulmonary complaints to a therapist in a local health facility. After further examination in the ZRTBCD, he was admitted to the PTD No 3 with the diagnosis: MDR-TB (new case), infiltrative pulmonary $T B$ in the upper lobe of the right lung, phase of dissemination, destruction + (several cavities up to $3.5 \mathrm{~cm}$ in diameter), $M B T+$, smear $(S)+$, molecular genetic test $(M G)+$, culture $(C)+$, rifampicin resistance $($ Rif $)+$, resistance 1 (isoniazid - $\mathrm{H}$, rifampicin - $\mathrm{R}$, streptomycin - $\mathrm{S}$, ethambutol $-\mathrm{E}$ ), resistance 2 (kanamycin $-\mathrm{Km}$, capreomycin $-\mathrm{Cm}$ ). The AMBT regimen was initiated based on the DST results.

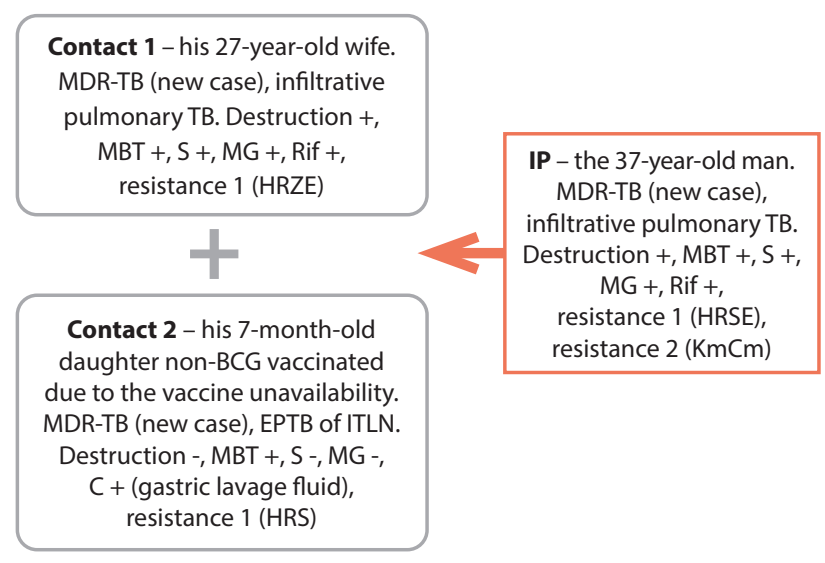

Fig. 1. The $1^{\text {st }}$ household contact investigation of the MDR-TB patient

The IP lived with his 27-year-old wife and 7-month-old daughter. The contact persons were examined immediately after the source MDR-TB patient was detected. The wife had no complaints of her general condition deterioration. However, her chest X-ray showed changes and she was sputum-smear positive. After further examination, she was diagnosed with MDR-TB (new case), infiltrative pulmonary TB in the upper lobe of the left lung, destruction + (cavity up to $1 \mathrm{~cm}$ in diameter), MBT +, $\mathrm{S}+, \mathrm{MG}+, \mathrm{C}+$, Rif + , resistance 1 (HRS, pyrazinamide $-\mathrm{Z}$ ) and also admitted to the PTD No 3. The AMBT regimen was initiated based on the DST results of her husband.

The 7-month-old infant had not been vaccinated with BCG at birth due to the vaccine unavailability. Upon admission to the Pediatric Department, the child was diagnosed with grade 2 rickets (moderate-to-severe, period of remission); acute postnatal cytomegalovirus infection with liver involvement, convalescent-phase; meningeal brain dysfunction, pyramidal insufficiency syndrome. Results of the examination: Mantoux test $-12 \mathrm{~mm}$, recombinant tuberculosis allergen (RTA) test - $13 \mathrm{~mm}$; a chest computer tomogram (CT) scan showed enlarged intrathoracic lymph nodes (ITLN), abdominal ultrasound (US) revealed hepatosplenomegaly. As a sputum examination was not possible, a gastric lavage fluid was examined. MBT bacterioscopy and MG tests were negative. Based on the follow-up data, the child was diagnosed with a risk of MDR-TB (RMDR-TB) (new case), extrapulmonary TB (EPTB) of ITLN, destruction -, MBT -, S -, MG -, Rif -, resistance (contact with her HRSE father). The AMBT regimen was initiated based on father's (IP) DST results. A month later, gastric lavage fluid culture results were obtained showing $\mathrm{C}+$ and resistance to HRS. The child was diagnosed with MDR-TB (new case), EPTB of ITLN, destruction -, MBT +, S -, MG -, Rif -, $\mathrm{C}+$, resistance 1 (HRS).

Thus, in the household 1 , a follow-up of the contacts was carried out immediately after the identification of MDR-TB source (IP). The child had not been vaccinated with BCG and had comorbidities. Despite the fact that 7-month-old infant had TB of ITLN, her own DST results (MBT drug resistance) were obtained via the gastric lavage fluid. All 3 family members were diagnosed with MDR-TB. Drug resistance profiles were: IP (father) - HRSE, contact (mother) - HRSZ, contact (child) - HRS. 


\section{ОРИГІНАЛЬНЕ ДОСЛІДЖЕННЯ}

Household 2 (fig. 2). The IP is a 25 -year-old woman (mother) with no previous history of TB. She was diagnosed with TB by a doctor in a local health facility followed by further examination and admission with the diagnosis: MDR-TB (new case), infiltrative pulmonary TB in the lower lobe of the left lung, phase of dissemination, destruction + (cavity up to $2 \mathrm{~cm}$ in diameter), $\mathrm{MBT}+, \mathrm{S}+, \mathrm{MG}+, \mathrm{C}+$, Rif +, resistance 1 (HRSEZ). HIV infection, clinical stage 4 (CD4 T-lymphocyte count - 338 cells/ $\mu$ l). Antiretroviral therapy (ART) was started in addition to the AMBT regimen based on the DST results.

\begin{tabular}{|c|c|}
\hline $\begin{array}{c}\text { Contact - her daughter aged } \\
1 \text { year and } 2 \text { months (non-BCG } \\
\text { vaccinated due to the medical } \\
\text { contraindication to vaccination } \\
\text { R75). RMDR-TB (new case), MBTC, } \\
\text { destruction -, MBT -, S -, MG -, } \\
\text { C +, Rif -, resistance } \\
\text { (contact with her HRSEZ mother) }\end{array}$ & $\begin{array}{l}\text { IP } \text { - the } 25 \text {-year-old } \\
\text { mother. MDR-TB (new case), } \\
\text { infiltrative pulmonary TB } \\
\text { in the lower lobe of the left } \\
\text { lung with dissemination. } \\
\text { Destruction }+, \text { MBT }+, \mathrm{S}+\text {, } \\
\text { MG }+, \mathrm{C}+\text {, Rif }+ \text {, } \\
\text { resistance } 1 \text { (HRSEZ). } \\
\text { HIV infection, clinical stage } 4\end{array}$ \\
\hline
\end{tabular}

Fig. 2. The $2^{\text {nd }}$ household contact investigation of the MDR-TB patient

The IP lived with her husband (28 years) and her daughter (1 year, 2 months). The contact persons were examined immediately after the source MDR-TB patient was detected. There were no data on active TB infection in husband after further examination. The contact child had not been vaccinated with BCG at birth due to a medical contraindication to vaccination R75 (child born to the HIV infected mother (Z20.6; R75), undetermined child's HIV status). During the follow-up examination, the child was diagnosed with severe concomitant pathology: hydrocephalus, grade 2 rickets (moderate-to-severe, period of remission); acute postnatal cytomegalovirus infection. The diagnostic results: Mantoux test $-10 \mathrm{~mm}$, RTA test $-13 \mathrm{~mm}$, a chest CT scan showed MBT complex (MBTC), abdominal US revealed hepatosplenomegaly. The child was examined for gastric lavage fluid, and MBT was not detected by all the methods. Diagnosis: MDR-TB (new case), MBTC, destruction -, MBT -, S -, MG -, Rif -, resistance (contact with HRSEZ mother). AMBT regimen was prescribed based on the DST results of the IP.

Thus, the contacts of household 2 were investigated immediately after the IP detection. There were no medical data on TB infection or active disease in husband. The non$B C G$ vaccinated child with severe concomitant pathology was diagnosed with active TB.

Household 3 (fig. 3). The IP is a 36-year-old man (father). He recalled being initially diagnosed and treated for TB when he was a prisoner 7 years previously and switched to Category 5.1 with residual changes after cured TB. In this case, the patient was coinfected with HIV (clinical stage 4) and chronic hepatitis $\mathrm{C}$ virus (HCV) infection. He was diagnosed with MDR-TB during TB relapse a year ago and considered as having treatment failure after AMBT completion. It was a family of displaced persons. After resettling in the Zaporizhzhia region, the patient was admitted to the ZRTBCD and diagnosed with XDR-TB, infiltrative right-sided pulmonary $T B$, destruction + (one cavity with a diameter of $1.5 \mathrm{~cm}$ ),
$\mathrm{MBT}+, \mathrm{S}+, \mathrm{C}+$, resistance 1 (HRZSE), resistance 2 (levofloxacin - Lfx, moxifloxacin - Mfx, ofloxacin - Ofx, ethionamide - Et); HIV infection, clinical stage 4 (CD4 T-lymphocyte count - 1084 cells/ $\mu$ l); chronic HCV infection. A new course of AMBT was started taking into account the DST results with ART initiation.

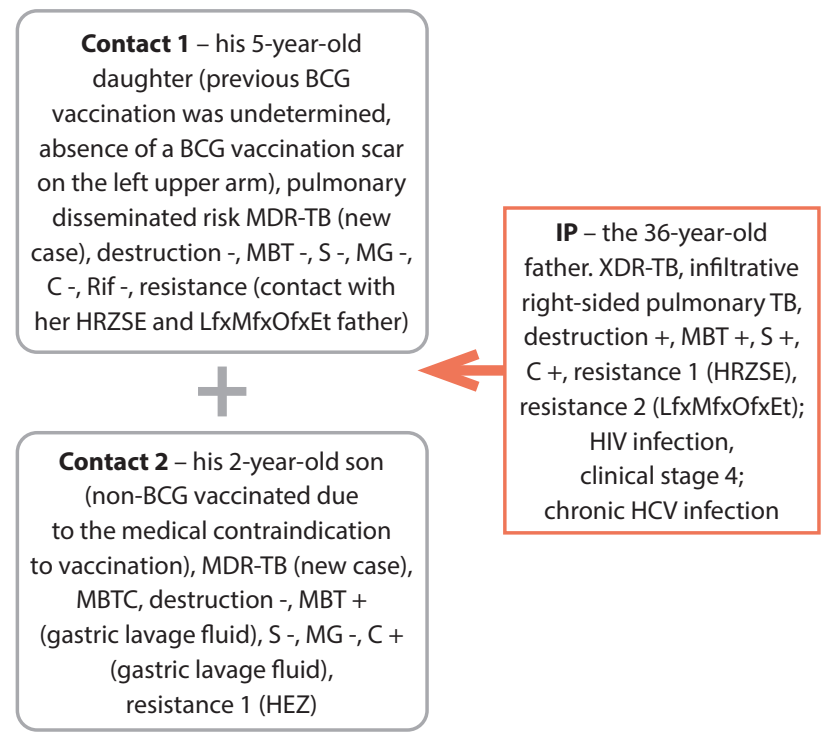

Fig. 3. The $3^{\text {rd }}$ household contact investigation of the MDR-TB patient

The IP (father) lived with his wife and 2 children (a 5-year-old daughter and a 2-year-old son). Initial detailed examination of his wife and children revealed no data on TB infection or active disease. However, both children simultaneously were diagnosed with MDR-TB and presented the following changes one year after their father had been diagnosed with TB relapse identified as MDR-TB.

In the 5-year-old daughter (non-BCG vaccinated): Mantoux test $-17 \mathrm{~mm}$, RTA test $-18 \mathrm{~mm}$; a chest CT scan showed disseminating process in the lungs without cavitation; abdominal US revealed hepatosplenomegaly. The child's sputum and gastric lavage fluid specimens were examined for MBT and all methods tested negative. The diagnosis was made: disseminated pulmonary risk MDR (new case), destruction -, MBT -, S -, MG -, Rif -, resistance (contact with her HRSEZ and LfxMfxOfxEt father). The AMBT regimen was started based on father's (IP) DST results.

The 2-year-old son was non-BCG vaccinated due to a medical contraindication. The diagnostic findings: Mantoux test - $17 \mathrm{~mm}$, RTA test $-23 \mathrm{~mm}$, no cavitation on a chest CT scan, abdominal US showed hepatosplenomegaly. The diagnosis was made: RMDR-TB (new case), MBTC, destruction -, MBT -, S -, MG -, Rif -, resistance (contact with his HRSEZ and LfxMfxOfxEt father). The AMBT regimen was started based on father's (IP) DST results. A month later, gastric lavage fluid culture results were obtained revealing resistance to HEZ following that the child was diagnosed with polyresistant TB (new case), MBTC, destruction -, MBT -, S -, MG -, Rif -, $C+$, resistance 1 (HEZ). But the continuation of $A M B T$ scheme accounted his father's DST results. 


\section{ОРИГІНАЛЬНЕ ДОСЛІДЖЕННЯ}

Thus, the contacts of household 3 were continuously examined in detail immediately after diagnosis of the IP, but both children were simultaneously found to have active TB a year after the diagnosis of XDR-TB in their father (IP). However, both children were non-BCG vaccinated. The IP's wife did not present clinical findings on TB infection or active disease.

Household 4 (fig. 4). The IP is a 27-year-old man who had being on palliative care in the Regional TB hospital in the Veselianka village (the Zaporizhzhia region) at the time of contact tracing. He was diagnosed with pulmonary fibro-cavernous XDR-TB, destruction +, MBT +, S +, C +, resistance 1 (HRZSE), resistance 2 ( $\mathrm{LfXMfxCm})$. He lived in the village in a private house with his father, mother and brother, who were continuously screened as contact persons. At the time of TB diagnosing in the contact persons, the IP had been suffering from XDR-TB for 2 years. Clinical findings related to TB infection or active disease were found in the mother. The IP's father (a 48-year-old contact 1) had an infiltrative destructive process and was hospitalized after detailed examination diagnosed with RMDR-TB (new case), infiltrative TB of the upper lobe of the right lung, destruction + (1 cavity up to $1.0 \mathrm{~cm}$ in diameter), MBT -, S -, MG -, Rif -, resistance (contact with his HRZSE and LfXMfxCm son). He was initiated on TB treatment based on his son (IP) DST results. The brother (a 25-year-old contact 2) was also referred to the ZRTBCD. However, after examination, he was diagnosed with XDR-TB (new case), MBTC, destruction +, MBT +, S +, MG +, Rif +, resistance 1 (HREZ), resistance 2 (LfxMfxCmEt). Therefore, the IP's brother started an AMBT regimen based on his own MDS results.

Contact 3 was a 7-year old child (a granddaughter of contact 1 and a daughter of the IP). The girl did not have a relationship with her father since the age of 2, but she communicated with her grandfather (contact 1 ) regularly and with her uncle (contact 2) occasionally. The child lived in a private house (3 rooms) in a multi-child family: mother, stepfather, 3 sisters $(6,8,16$ years) and 2 brothers ( 9 and 12 years). The child was BCG vaccinated, a BCG vaccination scar of $5 \mathrm{~mm}$. She had tuberculin skin test conversion 3 years ago and was followed-up in the Category 5.4 of dispensary observation (a preventive treatment was not received). After the grandfather (contact 1 ) and the uncle (contact 2 ) admission, the child was examined in detail: Mantoux test $-15 \mathrm{~mm}$ with vesicle,
RTA test - $18 \mathrm{~mm}$, a chest CT scan showed enlarged ITLN without destructions, abdominal US revealed hepatosplenomegaly, all methods of sputum examination tested negative for MBT. The child was referred to hospital with a diagnosis of RMDR-TB (new case), EPTB of ITLN and axillary lymph nodes (LN), destruction -, MBT -, M -, MG -, Rif -, resistance (contact with her grandfather who was the contact of her HRZSE and LfxMfxOfxCm father - the IP). A treatment was started based on the IP's DST results. The child's family was further examined and there were no data on TB infection or active disease.

Contact 4 was a 4-year-old child (a daughter of contact 2). The father had not lived with his child for 2 years but had visited her periodically. The child lived in a private house with her mother and brother (2-year-old), who were not confirmed with TB infection or active disease after examination. The child being non-BCG vaccinated was examined in detail after her father's (the source and contact 2) admission to the hospital: Mantoux test $-18 \mathrm{~mm}$ with vesicle, RTA test $-18 \mathrm{~mm}$, a chest CT scan showed focal opacity without cavitations, abdominal US revealed hepatosplenomegaly, all methods of gastric lavage fluid examination tested negative for MBT. The child was admitted to the ZRTBCD with a diagnosis of RMDR-TB (new case), focal TB of the upper lobe of the right lung, destruction -, MBT -, S -, MG -, Rif -, resistance (contact with her HREZ and LfxMfxCmEt father). The treatment regimen was initiated based on her father's (contact 2) DST results.

Thus, in the household 4 , the contact persons were diagnosed with TB in 2 years after diagnosing XDR-TB in the IP. In this case, two children developed TB not being direct contacts of the IP, and they were infected after exposure to adult contacts of the IP (contact 1 and 2). One child was BCG vaccinated, but the other was not. The children were proved to be non-MBT by microbiological tests.

Household 5 (fig. 5). The IP is a 24-year-old woman admitted to the hospital with the diagnosis: pulmonary infiltrative right-sided MDR-TB (new case), destruction +, MBT +, S +, $\mathrm{MG}+$, Rif,$+ \mathrm{C}+$, resistance 1 (HRSEZ). The treatment regimen was based on her DST results. She lived in a two-room apartment with a mother and a child aged 1 year and 11 months. The IP's mother did not present clinical data on TB. The child was non-BCG vaccinated. The following changes were noticed after the child's examination: Mantoux test - $14 \mathrm{~mm}$,

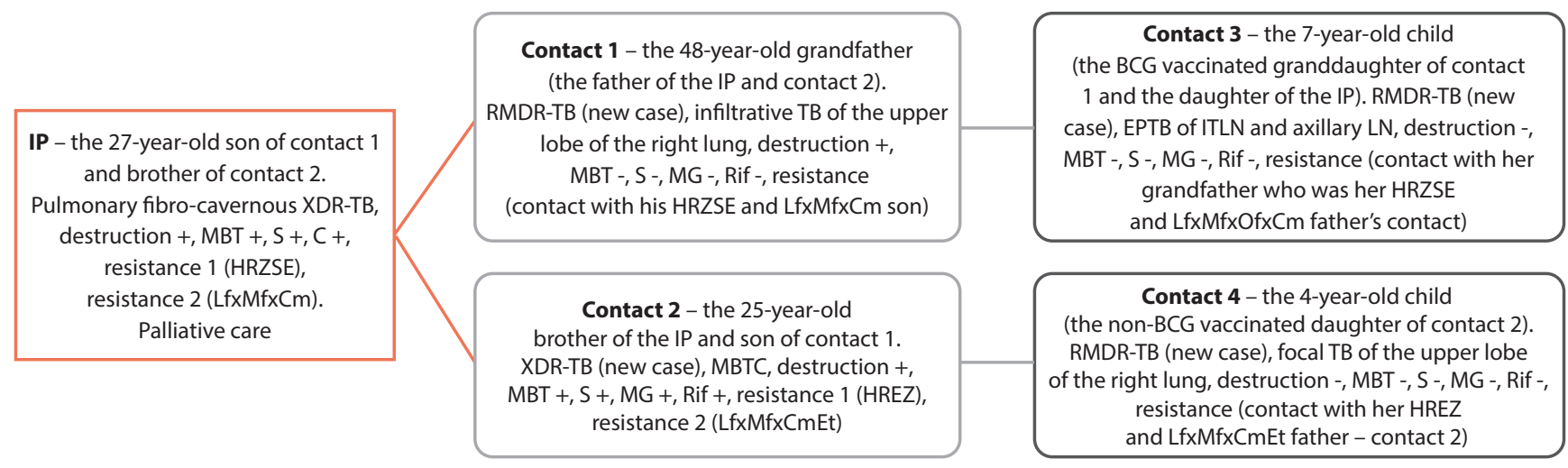

Fig. 4. The $4^{\text {th }}$ household contact investigation of the MDR-TB patient 
RTA test - $15 \mathrm{~mm}$ with vesicle, a chest CT scan revealed enlarged ITLN without destructions, abdominal US showed hepatosplenomegaly, all methods of gastric lavage fluid examination tested negative for MBT. The child was referred to the ZRTBCD in a week after her mother was admitted with a diagnosis: RMDR-TB (new case), TB of ITLN, destruction -, MBT -, S -, MG -, Rif -, resistance (contact with her HRSEZ mother). The treatment regimen was started based on her mother's (the IP) DST results.

\begin{tabular}{|c|c|}
\hline $\begin{array}{c}\text { Contact }- \text { her daughter, } \\
\text { aged } 1 \text { year and } 11 \text { months, } \\
\text { non-BCG vaccinated. RMDR-TB } \\
\text { (new case), TB of ITLN, } \\
\text { destruction -, MBT -, S -, MG -, } \\
\text { Rif -, resistance (contact with her } \\
\text { HRSEZ mother) }\end{array} \begin{array}{c}\text { IP - the 24-year-old mother. } \\
\text { Pulmonary infiltrative } \\
\text { right-sided MDR-TB } \\
\text { (new case). }\end{array}$ \\
$\begin{array}{c}\text { Destruction }+, \text { MBT +, S +, } \\
\text { MG +, C +, Rif +, } \\
\text { resistance } 1 \text { (HRSEZ) }\end{array}$ \\
\hline
\end{tabular}

Fig. 5. The $5^{\text {th }}$ household contact investigation of the MDR-TB patient

Thus, contact tracing in household 5 was conducted immediately after the IP detection. The IP's mother was not found to have TB infection or active TB. The non-BCG vaccinated child younger than 2 years of age was diagnosed with active TB.

Household 6 (fig. 6). The IP is 57-year-old male had no prior TB history. He was admitted to the hospital with the diagnosis: rifampicin-resistant TB (Rif-TB) (new case), pulmonary disseminated TB of the upper lobes, destruction -, $\mathrm{MBT}+, \mathrm{S}-, \mathrm{MG}+, \mathrm{C}+$, Rif +. The diagnosis was confirmed by DST results (resistance $1-H$ ) in 3 weeks: MDR-TB, resistance $1(H R)$. He lived in a village in a four-room private house with his wife, daughter, daughter's husband and 5 grandchildren (9, 8, 5 years of age, 2 year-old twins). A household-based follow-up for all contact persons did not identify the wife, the daughter's husband and the children of 8 and 9 years of age with TB infection or active TB.

The daughter (contact 1) was found to have changes based on a chest X-ray and after further examination she was admitted to the hospital diagnosed with: Rif-TB (new case), pulmonary disseminated TB of the upper lobes, destruction -, $\mathrm{MBT}+, \mathrm{S}-, \mathrm{MG}+, \mathrm{C}-$, Rif +, resistance (contact with her HR father). The AMBT regimen was started based on her father's (IP) DST results.

The 5 -year-old son of the daughter (contact 1.1, BCG vaccinated, a BCG vaccination scar of $2 \mathrm{~mm}$ ) presented with Mantoux test - $15 \mathrm{~mm}$, RTA test $-17 \mathrm{~mm}$, a chest CT scan revealed changes in the left lung, abdominal US showed moderate hepatosplenomegaly, all methods of gastric lavage fluid examination tested negative for MBT. The diagnosis was established: RMDR-TB (new case), MBTC in the left lung, destruction -, MBT -, S -, MG -, Rif -, resistance (contact with his HR grandfather). The AMBT regimen was prescribed based on grandfather's (IP) DST results.

Both of the 2-year-old twins (contacts 1.2 and 1.3) were BCG vaccinated with BCG vaccination scars of $2 \mathrm{~mm}$. In a girl (contact 1.2), Mantoux test was $15 \mathrm{~mm}$, RTA test $16 \mathrm{~mm}$, a chest CT scan revealed enlarged ITLN of the left lung without destruction, abdominal US showed moderate hepatosplenomegaly, and she was diagnosed with RMDR-TB (new case), right-sided ITLN-TB, destruction -, MBT +, S -, $\mathrm{MG}+, \mathrm{C}+$, Rif -, resistance (contact with her HR grandfather). The AMBT regimen was initiated based on the grandfather's (IP) DST results. In a boy (contact 1.3), Mantoux test was $14 \mathrm{~mm}$, RTA test - $16 \mathrm{~mm}$, a chest CT scan revealed no changes, abdominal US showed moderate hepatomegaly, and he was diagnosed with tuberculin skin test conversion, TB contact, Category 5.2 A. A course of preventive treatment was started based on the grandfather's (IP) DST results.

The IP was constantly visited by a son (26-yearold contact 2) who lived with his wife and 3 children (a 2.5-year-old daughter and two 7- and 15-year old sons)

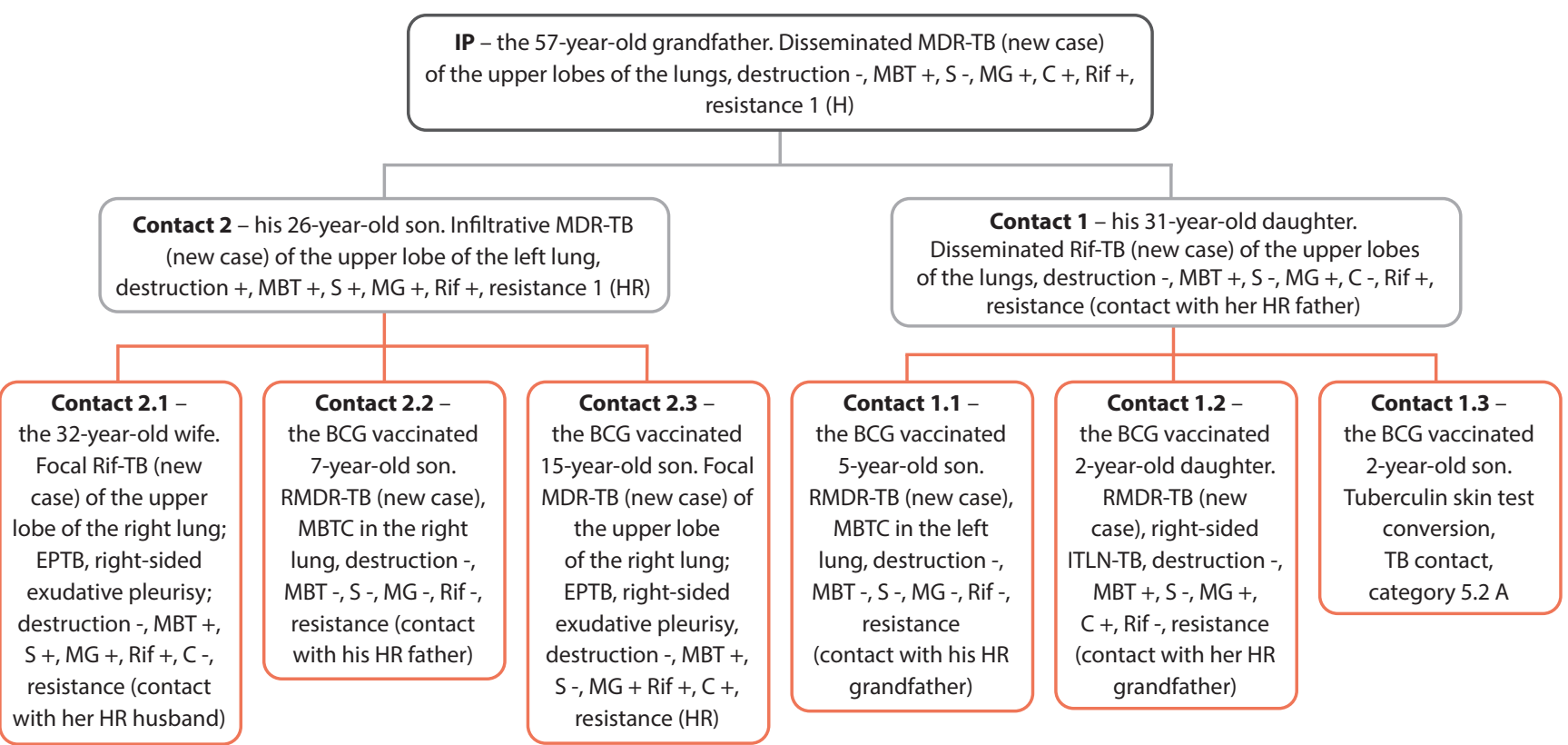

Fig. 6. The $6^{\text {th }}$ household contact investigation of the MDR-TB patient 
in a 3-room private house. After being examined, contact 2 was referred to the ZRTBCD diagnosed with Rif-TB (new case), left-sided pulmonary infiltrative TB of the upper lobe, destruction + (one cavity up to $3.5 \mathrm{~cm}$ in diameter), MBT +, $\mathrm{S}+, \mathrm{MG}+$, Rif +, resistance (contact with his HR father). Culture results of a sputum specimen obtained after 3 weeks indicated $\mathrm{C}+$ and the same resistance as the source had $(H)$. Therefore, the diagnosis was established: MDR-TB. The AMBT regimen was started based on the DST results.

Since contact 2 was diagnosed with Rif-TB, all members of his family were examined, among whom only the 2.5-yearold daughter did not present data on TB infection or active disease. The wife of contact 2 (32-year-old contact 2.1) was hospitalized diagnosed with Rif-TB (new case), focal TB of the upper lobe of the right lung; EPTB, right-sided exudative pleurisy; destruction -, MBT +, S +, MG +, Rif +, C -, resistance (contact with her HR husband). The AMBT regimen was prescribed based on her husband's DST results (contact 2).

Clinical findings in the BCG vaccinated 7-year-old son (contact 2.2, BCG vaccination scar of $8 \mathrm{~mm}$ ): Mantoux test $15 \mathrm{~mm}$, RTA test - $16 \mathrm{~mm}$, a chest CT scan showed changes in the right lung, abdominal US revealed moderate hepatomegaly, all methods of sputum examination tested negative for MBT. The child was diagnosed with RMDR-TB (new case), MBTC in the right lung, destruction -, MBT -, S -, MG -, Rif -, resistance (contact with his HR father). The AMBT regimen was initiated based on his father's DST results (contact 2).

Clinical findings in the BCG vaccinated 15-year-old son (contact 2.3, BCG vaccination scar was not found): Mantoux test $-12 \mathrm{~mm}$, RTA test $-16 \mathrm{~mm}$, a chest CT scan showed changes, abdominal US revealed moderate hepatomegaly. Culture results of a pleural fluid specimen indicated MBT resistance to HR. The boy was diagnosed with MDR-TB (new case), focal TB of the upper lobe of the right lung; EPTB, right-sided exudative pleurisy, destruction -, MBT +, S -, MG + Rif,$+ C+$ (pleural fluid), resistance 1 (HR). The AMBT regimen was started based on the DST results.

Thus, in household 6 , TB in contact persons (among 2 families) was detected immediately after diagnosing MDR-TB in the IP. All the contact children of both families were BCG vaccinated. In the IP's family, 3 (the IP's wife and two grandchildren aged 8 and 9 years) of the 7 contact persons did not have TB infection or active TB. One 2-yearold grandson was diagnosed with TB infection and was followed-up in the category 5.2 A of dispensary observation. 3 contact persons were diagnosed with active TB: the IP's daughter - disseminated Rif-TB, the 5- and 2-year old grandchildren presented changes on the chest CT (MBTC and TB of ITLN) without a microbiologically confirmed diagnosis. In the family of the IP's son, only 2.5-year-old daughter of the 5 contact persons had no clinical findings on TB infection or active disease. The IP's son with his wife had microbiologically confirmed TB - MDR-TB and Rif-TB, respectively. The 15-year-old son was positive for MTB resistant to $\mathrm{HR}$ in the pleural fluid (MDR-TB), and the 7-year-old son had MBTC without microbiological confirmation.

\section{Discussion}

This paper analyzes 6 households with 6 MDR-TB IP. A total of 25 contact persons were examined (fig. 7), of whom 15 persons (60\%) were $0-18$ years of age and 10 (40\%) individuals were over 18 years of age (adults). There were 14 children (56\%) and 1 teenager (4\%) among the 0-18 age group. Active TB was detected in 16 contact persons (64\%), of whom 11 were aged between 0 and 18 years (44\%) and 5 were adults (20\%). One contact 2-year-old child was found to be infected and followed-up in the Category 5.2 A of dispensary observation with a preventive AMBT initiation based on the IP's DST results.

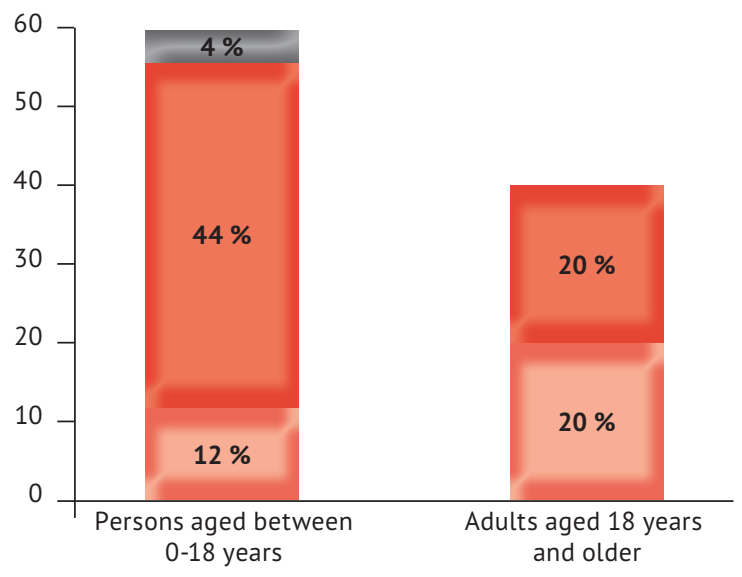

Fig. 7. Distribution of contact persons by age according to the TB infection and disease incidence

The nature of TB manifestations in child household contacts of MDR-TB patients was studied. Indeed, among 11 people aged between $0-18$ years, there were 1 teenager $(9.1 \%)$ and 10 children (90.9\%), of whom $6(54.5 \%)$ individuals were younger than 2 years of age, 2 (18.2 \%) - younger than 5 years and 2 (18.2 \%) - over 5 years of age.

7 children (63.6 \%) were non-BCG vaccinated: 5 (83.3 \%) of the 6 children aged younger than 2 years and both children (100\%) younger than 5 years of age.

The distribution of TB by clinical forms found that children younger than 2 years of age $(n=6)$ had TB of ITLN in 3 cases ( $50 \%)$, MBTC in 2 cases (33.3\%) and focal TB in 1 case (16.7\%); 1 case of disseminated TB and 1 case of MBTC were detected in children younger than 5 years of age $(n=2)$ as well as children older than 5 years $(n=2)$ were diagnosed with TB of ITLN (1 case) and MBTC (1 case); the teenager was diagnosed with focal TB.

6 children and 1 teenager (63.6\%) in 4 households (66.6\%) developed TB in the 1st year of MDR-TB IP's follow-up, in the 2 nd year - 2 children (18.2\%) in 1 household $(16.7 \%)$ and in the 3 rd year - 2 children (18.2 \%) in 1 household (16.7 \%).

MBT drug resistance was identified only in 3 children who were contacts of households exposed to MDR-TB: in 2 children younger than 2 years of age (in the gastric lavage fluid - HRS and HEZ) and in the adolescent (in the pleural fluid - HR).

The analysis of the concordance of MBT drug resistance profiles in households revealed the following:

1) in household 1, both the mother and her 7-month-old child had drug resistance profiles HRS that were completely concordant with that of the IP (father); 
2) in household 3, the 2-year-old child had isolates matched the resistance profiles (HEZ) of the IP (father) (the IP - HRSEZ and LfxMfxOfxEt, the child - HEZ);

3 ) in the household 4, children were proved to be non-MBT by microbiological tests, while the DST results in adults showed almost completely concordant resistance profiles HREZ and LfXMfXCm (the IP - HRZSE and LfxMfxCm, contact 2 - HREZ and LfxMfxCmEt);

4 ) in household 6, the MBT drug resistance profiles in the IP's son (contact 2) and the teenage grandson (contact 2.3) were found to be completely concordant with the IP for $\mathrm{HR}$ and the resistance profiles in 2 adult contacts (contact 1 and contact 2.1) were concordant with the IP for R;

$5)$ it was impossible to compare the drug resistance profiles in households 2 and 5 because children were not microbiologically confirmed.

All the children aged between 0 and 18 years received the AMBT regimen for RMDR-TB immediately after being diagnosed with active TB based on the DST results of the MDR-TB IP. The diagnosis was changed in 3 individuals ( 2 children younger than 2 years of age and 1 teenager) according to their own DST results obtained, nevertheless the treatment was continued as previously prescribed due to the complete concordance with that of the IP.

Thus, the tracing of children who were household contacts of the MDR-TB IP revealed the following features. The incidence of child TB was 2 times higher than that of contact adults (44\% vs. $20 \%$ ). Moreover, the incidence among children younger than 2 years of age was almost 3 times higher than in children across other age groups ( $54.5 \%$ vs. $18.2 \%$ in children younger than 5 years of age and $18.2 \%$ in children aged 5 years and older). The children were non-BCG vaccinated in $63.6 \%$ of cases. There was an alarmingly high rate of non-BCG vaccinated children, namely $83.3 \%$ among individuals younger than 2 years of age and all of those younger than 5 years of age (100\%). The children mostly presented small clinical forms of non-destructive TB: TB of the ITLN (36.4\%), MBTC (36.4\%) and focal TB (18.2\%).

Most of the children (63.6\%) who developed TB were detected within the first year of IP with MDR-TB follow-up, and it is worthy of note that in the majority of cases (4 households; $66.6 \%)$.

With respect to the concordance of MBT drug resistance profiles between the children and MDR-TB IP in the households, diagnosis in children was microbiologically confirmed in only 3 cases ( 3 households) demonstrating the complete concordance of profiles in each one. At the same time, the complete concordance of MBT drug resistance profiles between adult household contacts and the MDR-TB IP was also recorded in 3 cases.

As is evident, across the household contacts group aged between 0 and 18 years who were exposed to the MDR-TB IP, the most susceptible to develop TB were non-BCG vaccinated children younger than 2 years. More worryingly is that among 3 microbiologically conformed individuals of this age group, 2 children younger than 2 years were found to have their own drug resistant MTB isolates.

\section{Conclusions}

1. Tracing household child contacts of MDR-TB IP is particularly effective for timely detection of active TB within the first year of MDR-TB IP follow-up.

2. Non-BCG vaccinated children younger than 2 years of age are at the highest risk for MDR-TB followed by non$B C G$ vaccinated children younger than 5 years of age.

3. The early detection and timely AMBT initiation based on DST results of a MDR-TB IP is a guarantee not only for an effective treatment but also for a reduction in the MDR-TB transmission to other persons. 


\section{References}

1. Global Tuberculosis Report 2014. WHO/HTM/TB/2014.08. - 171 p.

2. Latent Tuberculosis Infection. WHO, 2018. CC BY-NC-SA 3.0 IGO.

3. Baghaie N., Khalilzadeh S., Bolursaz M.R., Parsanejad N. Contact tracing of a 15-year-old girl with smear-negative pulmonary tuberculosis in Tehran EMHJ. 2012; 18 (4): 399-401.

4. Paranjothy S., Eisenhut M., Lilley M., Bracebridge S., Abubakar I., Mulla R., et al. Extensive transmission of mycobacterium tuberculosis from 9 year old child with pulmonary tuberculosis and negative sputum smear. BMJ. 2008; 337: a1184. DOI: 10.1136/bmj.a1184.

5. Laghari M., Sulaiman S.A., Khan A.H., Talpur B.A., Bhatti Z., Memon N. Contact screening and risk factors for TB among the household contact of children with active TB: a way to find source case and new TB cases. BMC Public Health. 2019; 19: 1274. DOI: 10.1186/s12889-019-7597-0.

6. Becerra M.C., Appleton S.C., Franke M.F., Chalco K., Arteaga F., Bayona J., et al. Tuberculosis burden in households of patients with multidrug-resistant and extensively drug-resistant tuberculosis: a retrospective cohort study. Lancet. 2011; 377: 147-152. DOI: 10.1016/S0140-6736(10)61972-1.

7. Becerra M.C., Franke M.F., Appleton S.C., Joseph J.K., Bayona J., Atwood S.S., et al. Tuberculosis in children exposed at home to multidrug-resistant tuberculosis. Pediatr. Infect. Dis. J. 2013; 32 (2): 115-119. DOI: 10.1097/ INF.0b013e31826f6063.
8. Fox GJ. Barry S.E. Britton W.J., Marks G.B. Contact investigation for tuberculosis: a systematic review and meta-analysis. Eur. Respir. J. 2013; 41 (1) 140-156. DOI: 10.1183/09031936.00070812.

9. Lancellaa L., LoVecchiob A., Chiappinic E., Tadolinid M., Cirilloe D., Tortoli E. et al. How to manage children who have come into contact with patients affected by tuberculosis. Journal of Clinical Tuberculosis and Other Mycobacterial Diseases. 2015; 1: 1-12. DOI.org/10.1016/j.jctube.2015.07.002.

10. Companion handbook to the WHO guidelines for the programmatic management of drug-resistant tuberculosis. WHO/HTM/TB/2014.11. - 420 p.

11. Parr J.B., Mitnick C.D., Atwood S.S., Chalco K., Bayona J., Becerra M.C. Concordance of resistance profiles in households of patients with multidrugresistant tuberculosis. Clin. Infect. Dis. 2014; 58 (3): 392-395. DOI: 10.1093/ $\mathrm{cid} / \mathrm{cit} 709$.

12. Shah N.S., Yuen C.M., Heo M., Tolman A.W., Becerra M.C. Yield of contact investigations in households of patients with drug-resistant tuberculosis: systematic review and meta-analysis. Clin. Infect. Dis. 2014; 58 (3): 381-391. DOI: $10.1093 / \mathrm{cid} / \mathrm{cit} 643$.

13. Raznatovska O.M., Mironchuk Y. V Pushnova O.O., Chernishova L.I, Shelestina T.I., Bezdenezhney V.V. Features of tuberculosis in children not vaccinated with BCG vaccine. Zaporozhskij medicinskij zhurnal. 2018; 4 (109): 593-602. DOI: 10.14739/2310-1210. 2018.4.135754.

\section{Raznatovska Olena Mykolaivna}

Head of the Department of Phthisiology and Pulmonology of Zaporizhzhia State Medical University.

MD, PhD, Professor

2, Perspectyvna St., Zaporizhzhia, 69035, Ukraine.

ORCID iD: orcid.org/0000-0003-2252-9063

\section{Moskaliuk Alina Serhiivna}

Laboratory assistant of the Department of Phthisiology and Pulmonology of Zaporizhzhia State Medical University.

2, Perspectyvna St., Zaporizhzhia, 69035, Ukraine.

ORCID iD: orcid.org/0000-0003-4831-9486

\section{Grekova Tetiana Anatoliivna}

Assistant Professor of Department of Pathological Physiology of Zaporizhzhia State Medical University. PhD.

31, Stalevariv St., Zaporizhzhia, 69035, Ukraine.

ORCID iD: orcid.org/0000-0001-9946-3336

Chernyshova Liudmyla Ivanivna

Head of the children's ward of Municipal Institution "Zaporizhzhia Regional Tuberculosis Clinical Dispensary".

2, Perspectyvna St., Zaporizhzhia, 69035, Ukraine.

\section{Pushnova Oksana Oleksandrivna}

Pediatric phthysiologist at the Municipal Institution "Zaporizhzhia Regional Tuberculosis Clinical Dispensary".

2, Perspectyvna St., Zaporizhzhia, 69035, Ukraine.

\section{Shelestina Tetiana Ivanivna}

Pediatric phthysiologist at the Municipal Institution "Zaporizhzhia Regional Tuberculosis Clinical Dispensary".

2, Perspectyvna St., Zaporizhzhia, 69035, Ukraine. 